\title{
Spatial distribution of Canola culture in the State of Paraná (Brazil) between the agricultural years of 2005 and 2009
}

\author{
Suzana Costa Wrublack, Victor H.R. Prudente, Erivelto Mercante and Sílvia \\ R. Machado Coelho \\ Postgraduate Program in Agricultural Engineering, Western Paraná State University. 2069 Universitária St, \\ Cascavel, Paraná, Brazil.
}

\begin{abstract}
S.C. Wrublack, V.H.R. Prudente, E. Mercante, and S.R.M. Coelho. 2013. Spatial distribution of Canola culture in the State of Paraná (Brazil) between the agricultural years of 2005 and 2009. Cien. Inv. Agr. 40(3): 513-521. There are a number of crops that are viable for small farms. To increase our knowledge of the occurrence of canola cultivation in the State of Paraná, the present study aimed to identify the areas sown with canola (ha) and to examine canola production ( $t$ ) during the growing seasons of 2005 to 2009. The methodology involved a literature review and analysis of spatial data from the Secretaria da Agricultura e do Abastecimento do Paraná (SEAB/PR). We used the software ArcGis 9.3 for elaboration of thematic maps of variables as well as the free software GeoDa 0.9.5-i. The identification of spatial dependence was conducted through global univariate spatial autocorrelation using Moran's Index ( $I$ ) statistic and, at a local level, using Local Indicators of Spatial Association (LISA). Spatial correlation was detected in the data on the area sown (ha) and production (t) for the canola crop. The results also indicated the possibility of expansion of cultivated areas in the State of Paraná, in addition to providing interesting options regarding the composition of systems of crop rotation and soil cover. The application of the spatial statistical area contributed to the recognition of the evolution of the canola crop in the State of Paraná, based on the spatialization of production and sown areas in its municipalities. It is evident that most municipalities show no significant pattern, demonstrating the potential for the expansion of sown areas in the State. For the High-High standard, it was noted that the municipalities were grouped mainly in the western and south-central State of Paraná.
\end{abstract}

Key words: Spatial analysis, spatial correlation, statistic for areas, vegetation cover.

\section{Introduction}

Canola (Brassica napus L. var. oleifera) is a type of genetically modified oilseed rape, developed by Canadian breeders. It belongs to the family Brassicaceae and is grown in all grain production

Received April 25, 2013. Accepted October 14, 2013. Corresponding author:wrublack@hotmail.com systems in southern Brazil. Canola stands out as an excellent economic alternative because it is used to produce oils for human consumption as well as biodiesel ${ }^{1}$. In addition, canola meal has a high protein content (34 to $38 \%$ ), and it therefore serves as an important protein supplement in feed formulations for cattle, pigs, sheep and poultry (Tomm, 2007; Jacob Junior et al., 2012). 
In southern Brazil, the canola crop represents an interesting option in the composition of crop rotation systems or to be used as ground cover (Jacob Junior et al., 2012). Because it is a winter crop, canola provides an additional alternative for farmers in that period of the year. Thus, the cultivation of canola has great socioeconomic value as it creates opportunities for the production of vegetable oils in winter, coupled with soy production in summer (Tomm, 2007).

The levels of erucic acid and glucosinolates found in native rapeseed oil limit its consumption by humans and animals. For this reason, genetic modifications were introduced to reduce the levels of these substances and thus enable consumption of the oil extracted from these seeds, which is known as canola oil (Rosa et al., 2011).

The canola grains currently produced in Brazil contain approximately 24 to $27 \%$ protein and, on average, $38 \%$ oil (Tomm, 2007). They can be used to produce biodiesel, which is an environmentally sustainable alternative is an altern fuels (Alvarenga and Soares, 2010; Milani et al., 2012).

Given the importance of the cultivation of canola as an interesting option in the composition of crop rotation systems and the increasing importance of the use of its products, the present study aimed to identify the areas sown with canola and its production between 2005 and 2010 in the State of Paraná, Brazil.

\section{Materials and methods}

Official data on the production of canola in the State of Paraná for crop years 2005 to 2009 were obtained from the Secretaria da Agricultura e do Abastecimento do Paraná (SEAB/PR, 2010). The free software OpenGeoda 0.9.9.6 was used for spatial data analysis.

The Spatial Statistics area is a statistical method that makes use of geographical references on a template. The aim of this approach is to analyze the processes that occur in a geographic space and to describe and analyze the data related to these processes.

The spatial analysis of an area consists of a set of procedures aimed at finding an inferential model that expresses the constituents of the spatial relationships related to an event. Modeling of the exploratory analysis of spatial data is conducted in association with data visualization through charts and maps, and standards of the spatial dependence of the studied variables are subsequently identified. Exploratory Spatial Data Analysis directly addresses the effects of spatial dependence and spatial heterogeneity (Almeida et al., 2008).

To verify the existence of a pattern of spatial association, we used the Moran Index $(I)$. Moran's Index $(I)$ is a measure whose results indicate whether data are randomly distributed in space (Anselin et al., 2007). Moran's Index (I) is expressed in Equation (1); the equation for the deviation vector is expressed in Equation (2); and the equation for the weighted average is shown in Equation (3).

$$
\begin{aligned}
& I=\frac{Z^{T} \cdot W_{Z}}{Z^{T} \cdot Z} \\
& Z=\left(Z_{i}-\mu\right) 1^{T} \\
& W_{Z}=Z^{T} \cdot W^{\prime}
\end{aligned}
$$

Moran's Index $(I)$ ranges from -1 to 1 . Its expected value is defined by the equation $\mathrm{E}(I)=-[1 /(n-1)]$, where $n$ indicates the number of polygons in the area under study. A Moran's Index value of - [1/ $(n-1)] \mathrm{a}+1$ indicates positive spatial correlation, while a value of $-[1 /(n-1)]$ a -1 indicates negative spatial correlation. A value equal to the expected value $(I=\mathrm{E}(I))$ for the Moran Index indicates a lack of spatial correlation (Druck et al., 2004).

In this study, positive spatial autocorrelation can be represented by the similarity between coun- 
ties with high / low canola production ( $\mathrm{t}$ ), and the sown areas (ha) tend to be found in neighboring municipalities that also exhibit high / low production (t) and sown areas (ha) of canola. In contrast, a negative spatial autocorrelation indicates dissimilarity between the production of canola and its spatial location. Thus, municipalities with high / low canola production are neighboring municipalities that present a low / high value of this variable. To allow the best interpretation of Moran's Index (I), Moran Scatter Plots were created. These plots are graphics composed of four quadrants, representing the relationship between the values of vector $Z$ and the values of their weighted averages, $W z$. This diagram is divided into the following quadrants: High-High (HH); Low-Low (LL); High-Low (HL), and Low-High (LH). In this plot, the value of Moran's Index represents the slope of the regression line; i.e., this value indicates the slope of line $\mathrm{Wz}$ to $\mathrm{Z}$. This index is a global indicator of spatial autocorrelation that shows how the observed values of an attribute in a particular region (polygon) are dependent on this variable in neighborhood regions (polygons).

Determining Moran's Index (I) requires a weight matrix, $W$, also known as a spatial proximity matrix, which can consider three criteria of a neighborhood (Queen, Bishop and Tower). The Queen criterion, used in this study, considers the element $w_{\mathrm{ij}}=1$ if region $\mathrm{A}_{\mathrm{i}}$ shares a node in common with region $\mathrm{A}_{\mathrm{j}}$, whereas in all other cases, $w_{\mathrm{ij}}$ $=0$; for $\mathrm{i} \neq \mathrm{j}=1,2, \ldots, \mathrm{n}$ (Câmara and Monteiro, 2004 and Anselin et al., 2007).

In the calculations, the normalized spatial proximity matrix, $W^{\prime}$, is inserted; i.e., the elements of the rows of this matrix are multiplied by a given scale, so that their sum is normalized to a value of one. To obtain a vector of deviations (Z), another component of Moran's Index, first the average of the variable $(\mu)$, is calculated, and component $Z_{i}$ is subsequently found for $i=1,2, \ldots, n$, of vector $\mathrm{Z}$, and $\mathrm{Z}_{\mathrm{i}}=\left(\mathrm{x}_{\mathrm{i}}-\mu\right)$.
To calculate Moran's Index (I), the vector of weighted averages $\left(W_{z}\right)$ is also required. This parameter is obtained by multiplying the transposed vector of deviations $\left(\mathrm{Z}^{\mathrm{T}}\right)$ by the spatial proximity matrix with normalized rows. Thus, the average of the deviations of the neighbors of polygon $i$ is obtained in each element, $W_{z \mathrm{i}}$.

Spatial correlation is used to indicate standards of local association because although Moran's Index $(I)$ is able to reveal the general trend of data grouping, it is a global measure and therefore does not reveal patterns of local spatial association. Local autocorrelation can be calculated using the Local Moran's Index (I) statistic, also known as the Local Indicator of Spatial Association (LISA). The LISA for each municipality must provide an indication of significant spatial clusters of similar values around the county, and the sum of the LISA values for all municipalities is proportional to the Global Moran's Index (I) (Anselin, 1996).

The LISA statistic, or local Moran's Index (I), can be specified by Equation (3):

$I_{i}=\frac{x_{i}-\mu}{\sigma_{0}^{2}} \sum_{j=1}^{n} w_{i j}\left(x_{j}-\mu\right), i=1, \ldots, n$

in which is the population variance of the variable when studying $n$ municipalities; $x_{i}$ is the observation of a variable of interest in municipaliti; and $\mu$ is the average for $n$ municipalities (Cebebioglu and Dall'erba, 2009).

LISA provides an example of the disintegration of Moran's Index ( $I$ ), determining a specific value for each area (polygon) and allowing the identification of regions with outliers and clusters with similar values. The LISA index is represented by the following equation:

$I_{i}=\frac{\left(Z_{i} \cdot W_{Z_{i}}\right)}{\sigma^{2}}$,

where $v^{2}$ represents the variance of population data. 
Thematic maps of the variables canola production (t) and sown areas (ha) were generated with the aid of the software ArcGis 9.3 using the natural breaks tool (Jenks, 1971), which organizes the data in ascending order and groups them statistically based on the composition of pairs with adjacent characteristics, thus allowing data with similar characteristics to be grouped. These maps were divided into five quantitative categories to best represent the dataset.

\section{Results and discussion}

The area (ha) sown with canola in the crop years 2005, 2006, 2007, 2008 and 2009 is represented in the thematic maps shown in Figure 1. Figure 2 shows the thematic maps associated with the production of canola $(\mathrm{t})$ over the five crop years studied.

The analysis of the sown area (ha) data showed that there was an increase in the sown area during each examined harvest. The highest general average for this parameter in the crop years 2005-2009 was 1032 ha, for the Municipality of Cascavel. In addition, a gradual increase was observed in the number of municipalities that started to grow canola during the period under study.

Over the course of the study period, the yield (t) showed a significant increase. It was also observed that the average canola yield per city rose from 37.5 to $1454 \mathrm{t}$ during the study period.

Table 1 shows the values of Moran's Index (I) obtained for each harvest based on the data on the area sown with canola. It was observed that throughout the study period, the values of Moran's index $(I)$ were greater than the expected value of $E(I)=-[1 /(\mathrm{n}-1)]=-0.00251$. Thus, the existence of spatial correlation was demonstrated in the data on the area sown with canola.
Table 1. Moran's Index $(I)$ values in the crop years 2005 to 2009 .

\begin{tabular}{lcc}
\hline Harvests & $(I)_{\text {sown area }}$ & $(I)_{\text {yield }}$ \\
\hline $2005 / 06$ & 0.2112 & 0.1753 \\
$2006 / 07$ & 0.0926 & 0.0925 \\
$2007 / 08$ & 0.0814 & 0.0568 \\
$2008 / 09$ & 0.2385 & 0.2037 \\
$2009 / 10$ & 0.2680 & 0.2194 \\
\hline
\end{tabular}

The indication of positive spatial autocorrelation suggests that there may be similarity among the municipalities. Thus, municipalities with high production of canola tend to be neighboring municipalities that also exhibit high production, and municipalities with low production tend to be neighboring counties with similar production.

To visualize the possible spatial correlation of the variable canola production in the municipalities, Moran scatter plots were used. These plots seek to demonstrate the spatial dispersion of the variable of interest (canola cultivated in the examined districts) among quadrants, which are structured as follows: $\mathrm{HH}$, for areas with high values for a given attribute surrounded by municipalities showing high values for the same attribute; LL, for areas with low values for a particular attribute surrounded by areas presenting low values for the same attribute; HL, for areas with high values for a particular attribute surrounded by neighbors exhibiting low values for the same attribute; and $\mathrm{LH}$, for areas with low values for a given attribute surrounded by neighbors with high values for this attribute (Anselin, 1996).

To analyze the specific spatial correlation of the production of each municipality, the LISA index was used. LISA CLUSTER MAPS represent the Moran Scatter Plots, determining the clusters with low yields and high yields, where only the data reaching the level of significance $(\mathrm{P} \leq 0.05)$ are shown.

By analyzing the LISA MAPS, it can be observed that almost all municipalities containing sown areas 
2005

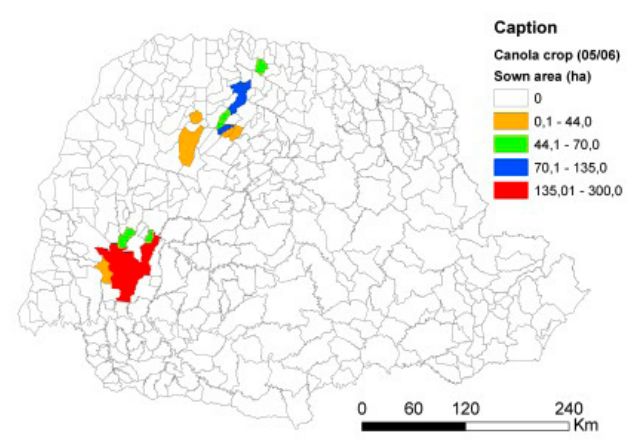

2007

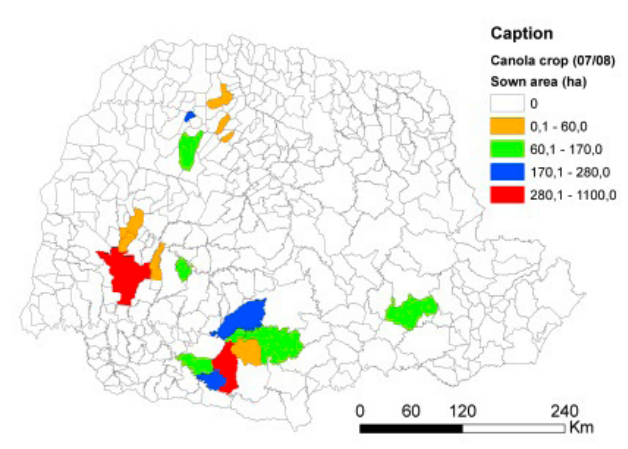

\section{6}

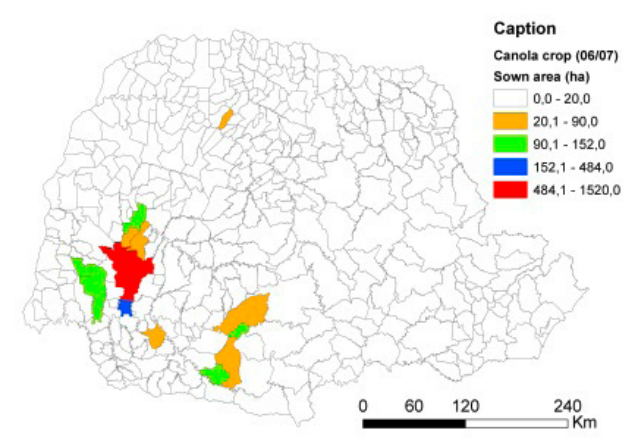

2008

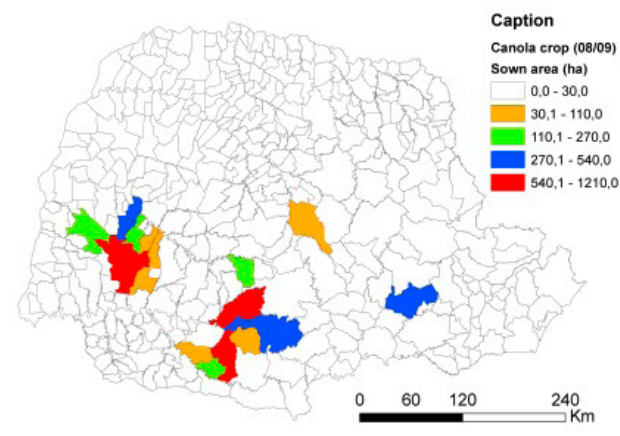

\section{9}
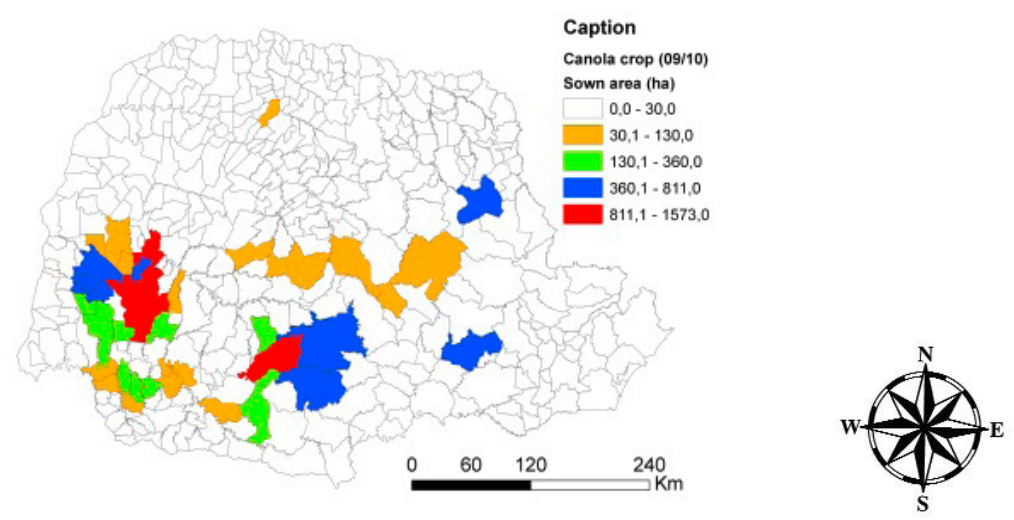

Figure 1. Area (ha) sown with canola in the State of Paraná.

(ha) of canola show spatial autocorrelation: $\mathrm{HH}$, HL and LH during the crop years under study. The municipalities located in the High-High quadrant represent locations with high values for the area sown with canola. The areas located in the HL and LH quadrants represent municipalities with sown areas (ha) that are surrounded by regions with high and/or low values for the area sown with canola in the State of Paraná (Figure 3).

For the reasons mentioned above for the preparation of LISA CLUSTER MAPS for the sown 


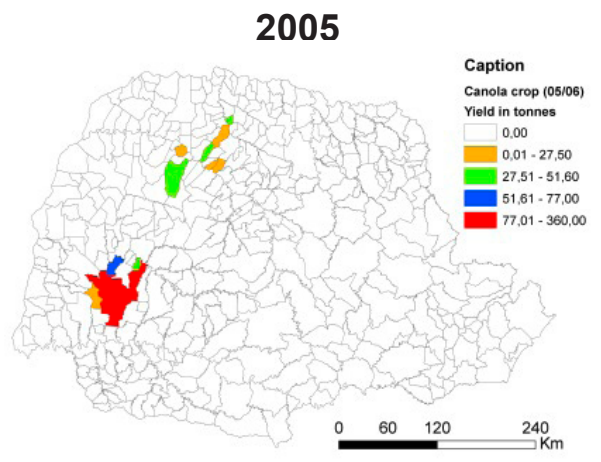

2007

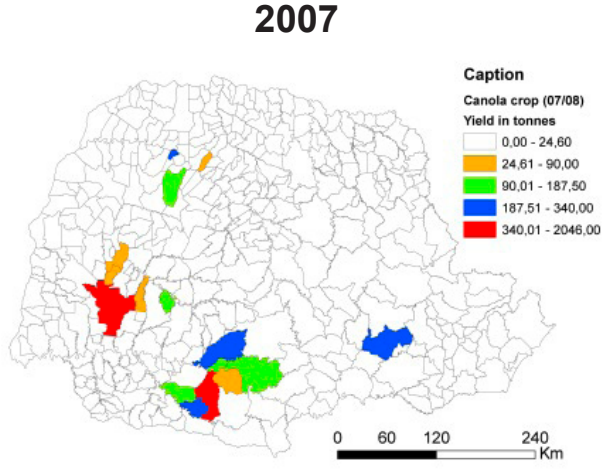

2009

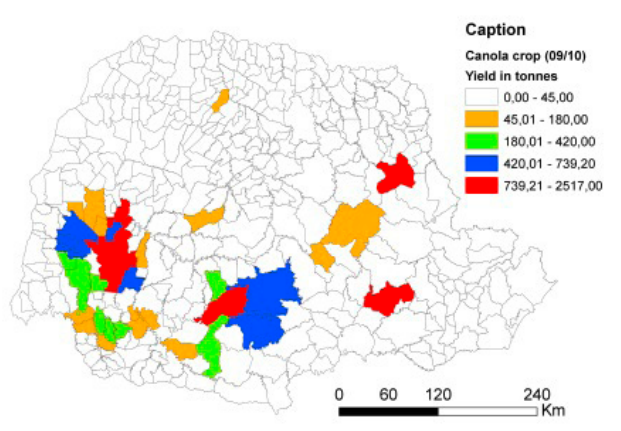

Figure 2. Yield (t) of canola in the State of Paraná.

area parameter, such maps were also generated for canola production among the municipalities, as shown in Figure 4.

The points located in the HH quadrant represent municipalities displaying high production of canola (above average) surrounded by municipalities that also exhibit high production. The areas located in the HL and LH quadrants represent municipalities with low and/or high production (t) that are surrounded by regions with high and/ or low canola production in the State of Paraná.

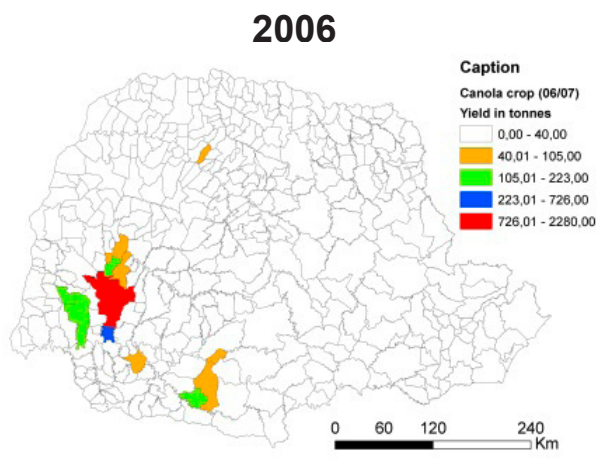

2008

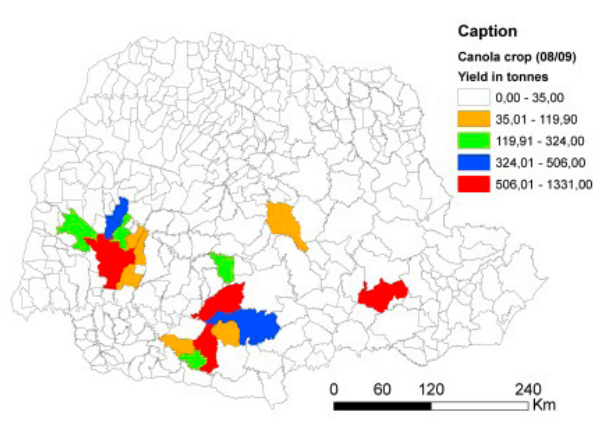

In the crop years 2006 and 2007, less spatial correlation was observed for both variables because the municipalities producing canola were further apart. In the crop years 2008 and 2009, two AA clusters were formed for both variables: one comprising the municipality of Cascavel and its neighbors (western Paraná) and one comprising the municipality of Pinhão and its neighbors (central-southern Paraná), in terms of both the cultivated area and canola yield.

The use of the spatial statistics area revealed the evolution of canola crop production in the 


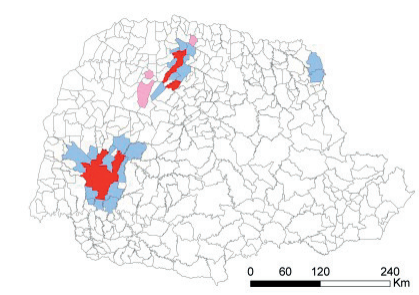

2008

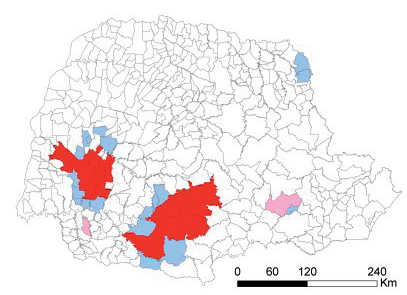

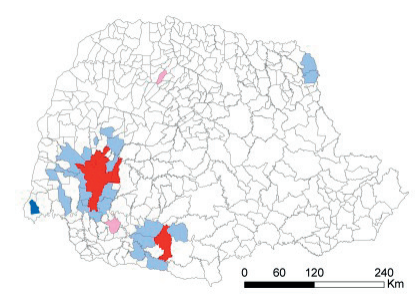

2009

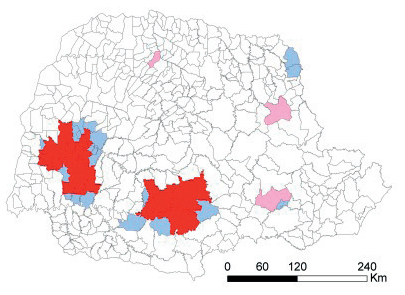

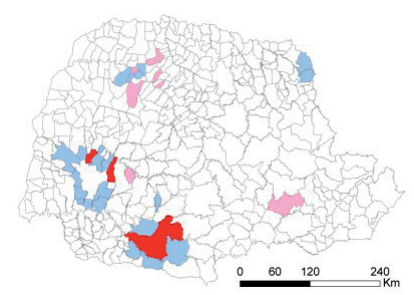

Caption

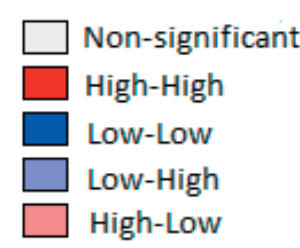

Figure 3. LISA CLUSTER MAPS for the data on the area (ha) sown with canola.

2005

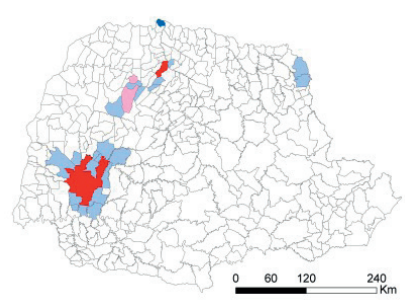

2008

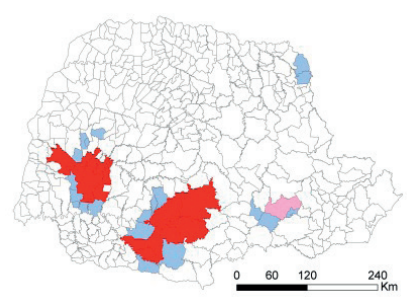

2006

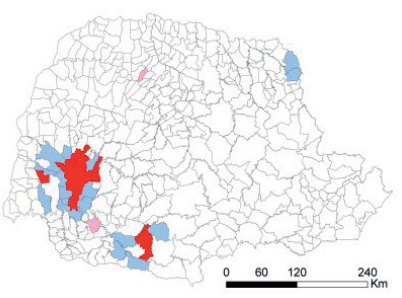

2009

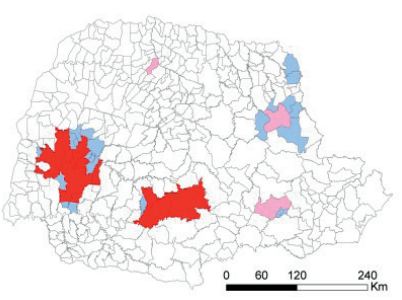

2007

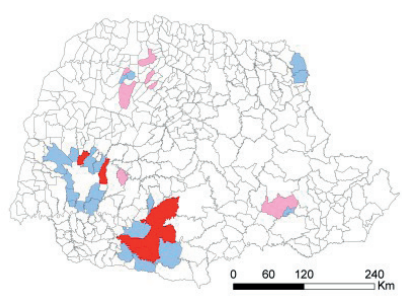

Caption

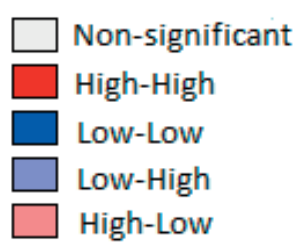

Figure 4. LISA CLUSTER MAPS for the data on the production $(t)$ of canola.

State of Paraná, together with the specialization of the production and sown areas among the municipalities.

It was shown that the area sown with canola and canola production are characterized by the existence of three types of spatial patterns (clusters):
$\mathrm{HH}, \mathrm{HL}$ and LH. Among these patterns, the most interesting is the $\mathrm{HH}$ cluster, found in western and southern-central Paraná because it represents two hubs of canola production in this State. Another highlight is the large number of municipalities that do not grow canola, indicating that there is room for expansion of the area sown in the State. 


\section{Acknowledgements}

The authors would like to thank the Secretaria da Agricultura e do Abastecimento do Paraná (SEAB/PR), Coordenação de Aperfeiçoamento de Pessoal de Nível Superior (CAPES), Conselho Nacional de Desenvolvimento Científico e Tecnológico (CNPq) and the Fundação Araucária, for their granting of scholarships and financial support.

\section{Resumen}

S.C. Wrublack, V.H.R. Prudente, E. Mercante y S.R.M. Coelho. 2013. Distribución espacial del cultivo de canola en el Estado de Paraná (Brasil) entre los años agrícolas de 2005 a 2009. Cien. Inv. Agr. 40(3): 513-521. Hay varios cultivos viables para las pequeñas fincas. A fin de proporcionar un mayor conocimiento de la ocurrencia del cultivo de canola en el Estado de Paraná, el presente estudio tuvo como objetivo identificar la superficie sembrada (ha) y producción de canola (t) durante el período de 2005 a 2009. La metodología implicó en una revisión de literatura y análisis de datos espaciales del Secretaria da Agricultura e do Abastecimento do Paraná (SEAB/PR). Se utilizó el software ArcGIS 9.3 para la preparación de mapas temáticos de las variables y el software libre OpenGeoda 0.9.9.6. La identificación de la dependencia espacial se realizó a nivel global mediante la autocorrelación espacial univariado por intermedio de la estadística I de Moran y a nivel local por el indicador local de asociación espacial (LISA). Fue observada la existencia de correlación espacial en el área de datos sembrada (ha) y producción ( $\mathrm{t}$ ) con cultivo de canola. Los resultados también indican que el Estado de Paraná tiene un gran potencial para la expansión del cultivo, además de ser una opción interesante para componer sistemas de rotación de cultivos y la cobertura del suelo. La aplicación de la estadística espacial de área, contribuyó al reconocimiento de la evolución de los cultivos de canola en el Estado de Paraná, a través de la distribución espacial de la producción y de las superficies sembradas de los municipios. Es evidente un mayor número de municipios sin un patrón significativo, lo que demuestra el potencial de expansión de la superficie a sembrar en el Estado. En el estándar Alto-Alto, se observó que los municipios se agrupan principalmente en la región occidental y centro-sur del estado del Paraná.

Palabras clave: Análisis espacial, cobertura vegetal, correlación espacial, estadística espacial de área, productividad.

\section{References}

Almeida, E.S. de, F.S. Perobelli, and P.G.C. Ferreira. 2008. Existe convergência espacial da produtividade agrícola no Brasil. Rev. Econ. Sociol. Rural, Brasília 46:31-52.

Anselin, L. 1996. Local Indicators of Spatial Association - LISA. Geographical Analysis. 27: 93-115.

Anselin, L. S. Sridharan, and S. Gholston. 2007. Using exploratory spatial data analysis to leverage social indicator databases: the discovery of interesting patterns. Social Indicators Research 82:287-309.
Alvarenga, B.M., and M.A. Soares. 2010. Potencialidade de produção de biodiesel por óleos e gorduras residuais na cidade de Itabira-MG. Ceres 57:721-729.

Câmara, G., and A.M.V. Monteiro. 2004. Conceitos básicos em ciência da g0eoinformação. São José dos Campos: Instituto Nacional de Pesquisas Espaciais (INPE). $346 \mathrm{pp}$.

Celebioglu, F., and S. Dall'erba. 2009. Spatial Disparities across the regions of Turkey: an exploratory spatial data analysis, The Annals of Regional Sciences 45:379-400. 
Druck, S., M.S. Carvalho, G. Câmara, and A.V.M. Monteiro. 2004. Análise Espacial de Dados Geográficos. Brasília: EMBRAPA. 209 pp.

Jacob Junior, E.A., L.M. Mertz, F.A. Henning, I.R. Quilon, M. Souza Maia, and J.M.D. Altisent. 2012. Changes in canola plant architecture and seed physiological quality in response to different sowing densities. Brasileira de sementes 34:14-20.

Jenks, G.F., and F. Caspall. 1971. Errors on choroplethic maps: definition, measurement, reduction. Ann. Assoc. Am. Geogr. 61:217-44. Available online at: http://www.tandfonline.com/doi/ pdf/10.1111/j.1467-8306.1971.tb00779.x (Web accessed: October, 2013).
Milani, M., N.L. Menezes, and S.J. Lopes. 2012. Teste de condutividade elétrica para avaliação do potencial fisiológico de sementes de canola. Ceres 59:374-379.

Rosa, A.S., B. Blochtein, and D.K. Lima. 2011. Honey bee contribution to canola pollination in Southern Brazil. Scientia Agrícola 68:255-259.

Tomm, G.O. 2007. Indicativos tecnológicos para produção de canola no Rio Grande do Sul. Passo Fundo: Embrapa Trigo, 2007b. 32 p. (Embrapa Trigo. Sistema de produção online, 3).Available online at: http://www.cnpt.embrapa.br/culturas/ canola/p_sp03_2007.pdf (Website accessed: May, 2013). 
